\title{
2,4-Thiazolidinedione in Well-Fed Lactating Dairy Goats: I. Effect on Adiposity and Milk Fat Synthesis
}

\author{
Shana Jaaf ${ }^{1,+}$, Fernanda Rosa ${ }^{1,+}$, Misagh Moridi ${ }^{2}$, Johan S. Osorio ${ }^{1, \ddagger}$, Jayant Lohakare ${ }^{3, \S}$, \\ Erminio Trevisi ${ }^{4}\left(\mathbb{D}\right.$, Shelby Filley ${ }^{1}$, Gita Cherian ${ }^{1}$, Charles T. Estill ${ }^{1}$ and Massimo Bionaz ${ }^{1, *(1)}$ \\ 1 Department of Animal and Rangeland Sciences, Oregon State University, Corvallis, OR 97331, USA; \\ shana.jaaf@oregonstate.edu (S.J.); Fernanda.Rosa@sdstate.edu (F.R.); Johan.Osorio@sdstate.edu (J.S.O.); \\ shelby.filley@oregonstate.edu (S.F.); gita.cherian@oregonstate.edu (G.C.); \\ Charles.Estill@oregonstate.edu (C.T.E.) \\ 2 Department of Animal Science, University of Guilan, Kilometer 5 of Rasht-Qazvin Highway, \\ Rasht 4199613776, Iran; moridimisagh64@gmail.com \\ 3 Department of Animal Biotechnology, Kangwon National University, KNU Ave 1, \\ Chuncheon 200-701, Korea; Johan.Osorio@sdstate.edu \\ 4 Department of Animal Sciences, Food and Nutrition (DIANA), Università Cattolica del Sacro Cuore, \\ Via Emilia Parmense, 84, 29122 Piacenza PC, Italy; erminio.trevisi@unicatt.it \\ * Correspondence: Massimo.bionaz@oregonstate.edu; Tel.: +01-541-737-9507 \\ + These authors contributed equally to this work. \\ $\ddagger$ Current address: Dairy and Food Science Department, South Dakota State University, Box 2104, \\ Brookings, SD 57007, USA. \\ $\S$ Current address: Department of Agriculture, University of Arkansas at Pine Bluff, 1200 N. University Drive, \\ Pine Bluff, AR 71601, USA.
}

Received: 28 March 2019; Accepted: 14 May 2019; Published: 17 May 2019

check for updates

\begin{abstract}
Background: In a prior experiment, treatment of goats with the putative PPAR $\gamma$ agonist 2,4-thiazolidinedione (2,4-TZD) did not affect milk fat or expression of milk-fat related genes. The lack of response was possibly due to deficiency of vitamin A and/or a poor body condition of the animals. In the present experiment, we tested the hypothesis that PPAR $\gamma$ activation affects milk fat synthesis in goats with a good body condition and receiving adequate levels of vitamin A. Methods: Lactating goats receiving a diet that met NRC requirements, including vitamin A, were injected with $8 \mathrm{mg} / \mathrm{kg}$ BW of 2,4-TZD $(n=6)$ or saline $(n=6$; CTR) daily for 26 days. Blood metabolic profiling and milk yield and components were measured including fatty acid profile. Expression of genes related to glucose and lipid metabolism was measured in adipose tissue and in mammary epithelial cells (MEC). Size of adipocytes was assessed by histological analysis. Results: NEFA, BHBA, and fatty acids available in plasma decreased while glucose increased in 2,4-TZD vs. CTR. Size of cells and expression of insulin signaling and glucose metabolism-related genes were larger in 2,4-TZD vs. CTR in adipose tissue. In MEC, expression of SCD1 and desaturation of stearate was lower in 2,4-TZD vs. CTR. Conclusions: Overall data revealed a lack of PPAR $\gamma$ activation by 2,4-TZD and no effect on milk fat synthesis despite a strong anti-lipolysis effect on adipose tissue.
\end{abstract}

Keywords: 2,4-thiazolidinedione; goat; milk fat; metabolism

\section{Introduction}

Butterfat is important for milk quality, especially for taste and flavor. Butterfat is also one of the most important components in the calculation of milk price received by dairy farmers in the US. Milk fat content is highly affected by the composition of the diet, especially dietary fat and fiber. 
The main components of dietary fat are long-chain fatty acids (LCFAs). They are known to have a nutrigenomic effect through modulation of transcription factors, especially peroxisome proliferator-activated receptors (PPARs) [1]. Among the three known PPAR isotypes, the PPAR $\gamma$ in mammary tissue of ruminants has been the most studied, and preliminary evidence supported a role of it in the regulation of milk fat synthesis [2]. Several subsequent in vitro studies performed on goat and bovine mammary epithelial cells confirmed the original observation [3-5].

Several in vitro studies were carried out using PPAR $\gamma$ agonists on dairy ruminants. The treatment of dairy cows with 2,4-thiazolidinedione (2,4-TZD), a putative PPAR $\gamma$ agonist, during the prepartum period did not affect milk fat percentage and either did not affect or numerically decreased milk fat yield in early postpartum cows [6]. Peripartum cows treated with the synthetic PPAR $\gamma$ agonist pioglitazone had a significant decrease in milk fat percentage and yield compared to cows not treated [7]. In both studies, the large decrease in plasma non-esterified fatty acids (NEFA) might partly explain the decrease in milk fat synthesis detected. In both studies, the decrease in plasma NEFA compared to the control group was between 23 and 28\%, while the decrease in milk fat yield was between 8 and 11\%. Plasma NEFA is an important source of preformed LCFA for milk fat synthesis and a positive relation exists between plasma NEFA and milk fat concentration [8]. Results from the above in vitro studies did not provide support for a positive effect of PPAR $\gamma$ activation on milk fat yield, but there was the confounding effect of the large decrease in NEFA, especially during the early postpartum period.

In a recent study in our laboratory, we treated dairy goats in mid-late lactation with TZD. Despite not having observed a decrease in NEFA, 2,4-TZD did not increase milk fat yield but tended to prevent milk fat decrease after induction of mammary infection [9]. Furthermore, we did not observe any large effect of 2,4-TZD on expression of classical PPAR $\gamma$ target genes in mammary epithelial cells (MEC) or adipose tissue, indicating that 2,4-TZD is, at best, a weak PPAR $\gamma$ agonist. These results confirmed the lack of effects of 2,4-TZD on expression of PPAR $\gamma$ target genes in adipose tissue of dairy cows during the close-up period [10]; however, another study detected a change in expression of several genes in adipose tissue after treatment with 2,4-TZD in non-pregnant dry cows [11]. Lack of activation of PPAR $\gamma$ by 2,4-TZD is also supported by findings from a recent study carried out in sheep with induction of milk fat depression by conjugated linoleic acid. Treatment with 2,4-TZD did not alleviate the negative effect on milk fat synthesis [12]. However, the same study detected a positive effect of 2,4-TZD on the expression of PPARG in mammary tissue and on lipogenic genes in adipose tissue.

In this prior goat study performed in our laboratory [9], the animals were not in an optimal body condition, and the hay-based diet was not supplemented adequately with vitamins, especially vitamin A. Vitamin A plays an important role in PPAR $\gamma$ activation, due to the agonistic effect of its metabolite 9-cis-retinoic acid on retinoic-X-receptor, the essential heterodimer of PPARs. The essential role of 9-cis-retinoic acid on the activation of PPARs by 2,4-TZD was supported by several in vitro studies carried out in bovine and caprine mammary cells [2].

For the above reasons, it remained to be determined if PPAR $\gamma$ plays a role in controlling milk fat synthesis in vivo. Therefore, it was necessary to repeat the prior experiment [9] by using dairy goats with good initial body condition and a balanced ration including the levels of vitamin A. Therefore, our hypothesis was that continuous activation of PPAR $\gamma$ by 2,4-TZD increases milk fat synthesis in dairy goats in a good body condition and supplemented with adequate amounts of vitamin A. The objective of the present study, which is part of a larger study, is to assess if the activation of PPAR $\gamma$ by 2,4-TZD increases milk fat synthesis.

\section{Materials and Methods}

\subsection{Experimental Design and Animal Management}

The Institutional Animal Care and Use Committees (IACUC) of Oregon State University (\#4448) approved all experimental procedures used in this study. Figure 1 depicts the whole study encompassing two objectives, one pertinent to the present manuscript and the other related to the companion 
manuscript [13]. For the study, we used 12 lactating Saanen goats (mean \pm SD) $52.6 \pm 16.2$ days in milk, $69.2 \pm 7.1 \mathrm{~kg}$ of body weight (BW), with a $2.6 \pm 0.2$ body condition score (BCS), with $1.7 \pm 0.6$ kids, and negative to milk bacterial analysis. For the experiment, goats were housed in individual pens and randomly assigned to treatment groups after blocking for body weight (BW), milk yield, and milk components. Goats were fed twice a day as described in detail in Appendix A. Dry matter and chemical composition of individual forages were determined by standard wet chemistry techniques at a commercial laboratory (Dairy One Forage Testing Laboratory, USA) (Table S1). The ration amount fed was calculated individually for each goat using BW and milk yield [14] (Table S2). Animals were drenched once daily to supply the level of vitamins required as described in Appendix A. See Table S3 for each component of the drench and the total amount of each vitamin provided.

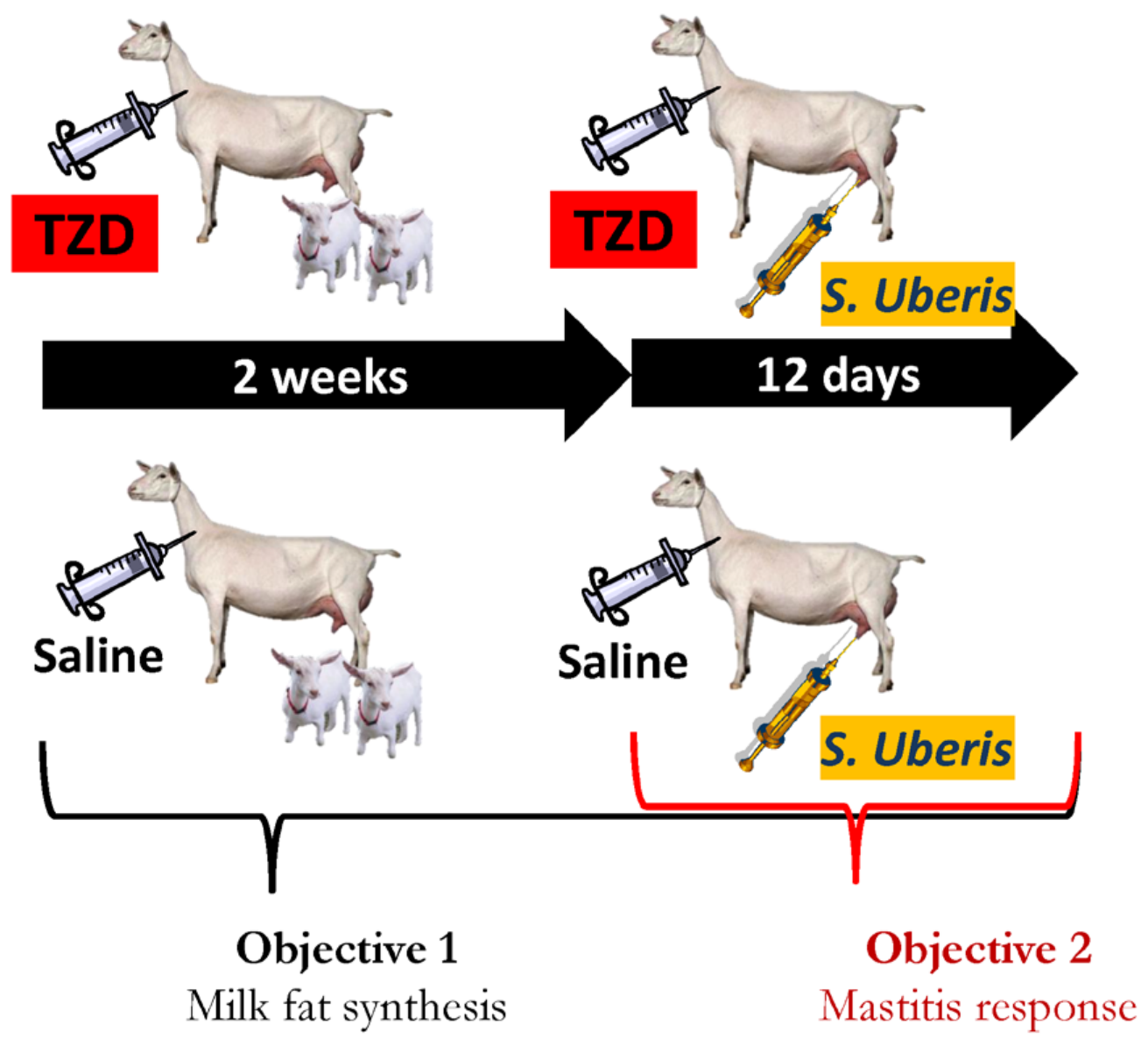

Figure 1. Experimental design. Twelve Saanen dairy goats were randomly assigned to receive a daily injection of $8 \mathrm{mg} / \mathrm{kg}$ BW of 2,4-thiazolidinedione (TZD) in $10 \mathrm{~mL}$ saline or only saline ( $n=6 /$ treatment) for 26 days. Kids (2 per goat) were kept nursing the goats for the first 10 days of the experiment. After 2 weeks of treatment the goats received an intramammary infusion of $7 \times 10^{8} \mathrm{cfu}$ of Strep. uberis in the right half of the mammary gland. All the TZD and three CTR goats were euthanized at the end of the experiment. The whole experiment was used to generate data for Objective 1 (present manuscript) and for Objective 2 in the companion manuscript [13].

\subsection{Treatments}

After the adaptation period, the goats started to receive at 10:00 a.m. daily injections via jugular vein of $8 \mathrm{mg} / \mathrm{kg}$ of BW of 2,4-thiazolidinedione (2,4-TZD; SC-216281, Santa Cruz Biotechnology, Dallas, TX, USA) in $10 \mathrm{~mL}$ sterile physiological saline (002479, Henry Schein, Dublin, OH) $(n=6$; TZD) throughout the whole study (26 days). Control group ( $n=6$; CTR) received $10 \mathrm{~mL}$ of sterile physiological saline without 2,4-TZD. Considering a BW of $70 \mathrm{~kg}$ and a molecular weight of 117.13 
$\mathrm{g} /$ mole, it was estimated that the maximum concentration in blood of 2,4-TZD after injection was approximately $190 \mathrm{mM}$, a dose known to activate PPAR in vitro in the presence of $10 \mu \mathrm{M}$ of 9-cis-retinoic acid [2]. An intramammary infusion with Streptococcus uberis in the right half of the mammary gland was performed in all goats on Day 15 of 2,4-TZD treatment (see companion papers for details [13]). The 2,4-TZD is not a compound approved by the FDA for use with animals or humans, but it is the backbone molecules used for the production of rosiglitazone and other FDA-approved compounds used to treat type II diabetes in humans $[15,16]$.

\subsection{Measurements, Sample Collection, and Blood Metabolites}

Details are available in Appendix A. Briefly, during the first 11 days of the experiment, while goats were nursed by the kids, milk yield was measured at Days $0,2,5$, and 10 of treatment by removing the kids at 8:00 p.m. and goats were immediately milked. The goats without the kids were milked again $12 \mathrm{~h}$ later, and we recorded milk yield and collected milk samples. After the kids were weaned (Day 11), goats were milked twice a day, and milk yield was measured at each milking (6:00 a.m. and 6:00 p.m.) until the end of the trial. For the present manuscript, only the milk from the left quarter (i.e., the quarter that did not receive the bacteria to induce infection, see [13]) during the morning milking was used to determine the amount of milk and milk composition. Milk samples were collected for analysis of somatic cells count (SCC), lactose, fat, protein, and solids non-fat (SNF) just before 2,4-TZD injection (time 0) and then at Days 2, 5, 15, 16, 17, 20, 21, and 22 of 2,4-TZD treatment. At Days 0, 2, 5, and 15 of 2,4-TZD treatment, additional samples were collected in $15 \mathrm{~mL}$ sterile tubes for fatty acid analysis. Details on dry matter intake (DMI), energy-corrected milk (ECM), dairy efficiency (DE), body condition score (BCS), and milk fatty acid analysis are available in Appendix A.

Blood samples were collected prior to treatment (time 0) and then on Days 7, 9, 15, 16, 17, 18,22 , and 26 for analysis of glucose, cholesterol, urea, creatinine, NEFA, triacylglycerol (TAG), and $\beta$-hydroxybutyric acid (BHBA) (see intra- and inter-assay variation in $[13,17])$. The analyses were performed following the procedures described previously $[17,18]$ using a clinical auto-analyzer (ILAB 650, Instrumentation). To check for replicability, a duplicate was performed for up to $10 \%$ of the samples selected randomly. Samples that were evident outliers or had dubious data were re-analyzed. The calculation of fatty acids available in blood was performed as $\mathrm{mM}$ of NEFA $+3 \times \mathrm{mM}$ of TAG. The percent variation of available fatty acids in blood was calculated as a percentage variation compared to time 0 in each goat.

\subsection{Adipose Biopsy and Histological Analysis, and Mammary Epithelial Cells Isolation}

Subcutaneous adipose tissue was collected by a biopsy as previously described [9] from alternate sides of the tail-head at around 10:00 a.m., and samples were flash-frozen in liquid nitrogen. The biopsy was performed on the day prior to starting 2,4-TZD and after 13 days of treatment. Adipose tissue was also collected after euthanasia for all 6 goats receiving 2,4-TZD and 3 random CTR goats. Euthanasia was performed using pentobarbital. MEC were isolated from $250 \mathrm{~mL}$ of milk using magnetic sorting on Day 4 of treatment. Details on the materials and methods used for histological analysis of the adipose tissue and MEC isolation are available in Appendix A. The KingFisher protocol file for MEC isolation is available in File S1, and the pipeline for CellProfiler is available in File S2.

\subsection{Reverse Transcriptase Quantitative Polymerase Chain Reaction (RT-qPCR)}

RNA was extracted from adipose tissue and MEC, and RT-qPCR was performed as described in detail in Appendix A. The purity of RNA (OD260/280) was $1.84 \pm 0.13$ for MEC and $1.90 \pm 0.12$ for adipose tissue (mean $\pm \mathrm{SD}$ ). The RNA integrity number (RIN) was assessed by electrophoretic analysis using 2100 Bioanalyzer Instruments (Agilent, Santa Clara, CA, USA) at the Center for Genome Research and Biocomputing, Oregon State University. The RIN values were (mean \pm SD) $5.5 \pm 0.25$ for adipose tissue samples and $5.6 \pm 1.5$ for MEC samples $(5.0 \pm 1.3$ for negative MEC and $6.3 \pm 1.4$ for positive MEC; $p=0.10$ ). 
The target genes selected to be evaluated in both MEC and adipose tissue were PPAR $\gamma$ (PPARG), lipoprotein lipase $(L P L)$, stearoyl-CoA desaturase 1 (SCD1), sterol regulatory element binding factor 1 $(S R E B F 1)$, acetyl-CoA carboxylase alpha $(A C A C A)$, very low-density lipoprotein receptor $(V L D L R)$, fatty acid translocase (CD36), and long-chain fatty acid transport protein 6 (SLC27A6). In adipose tissue, we also measured transcription of insulin receptor substrate 1 (IRS1), insulin receptor (INSR), fatty acid synthase (FASN), pyruvate dehydrogenase kinase 4 (PDK4), phosphoenolpyruvate carboxykinase 1 (PCK1), glycerol-3-phosphate dehydrogenase 1 (GPD1), and solute carrier family 2 (facilitated glucose transporter) member 4 (SLC2A4). For MEC, we also measured transcription of interleukin 8 (IL8), fatty acid binding protein 3 (FABP3), cytokeratin 8 (KRT8), nuclear factor (erythroid-derived 2)-like 2 (NFE2L2), nuclear respiratory factor 1 (NRF1), kappa-casein (CSN3), and lactalbumin alpha (LALBA). If not already designed [9], primer-pairs were designed as previously described [9]. Details of amplicon validation and selection of internal control genes are available in Appendix A. Details of primer pairs not previously published are available in Table S4.

\subsection{Statistical Analysis}

For each goat an arithmetical correction was performed to obtain the same average between groups at baseline as described previously [9]. Prior to statistical analysis, data were checked for outliers using PROC REG of SAS 9.4 (SAS Institute, Inc., Cary, NC, USA). Data with a studentized $t>3.0$ were removed. Data were analyzed with the PROC GLIMMIX. Fixed effects in the model were treatment, time, and the treatment $\times$ time interaction as main effects (or treatment, cell, and their interaction for the gene expression of MEC) and goat as random effect. The best covariance structure, either the spatial power, the autoregressive (1), or the autoregressive (1) with heterogeneous variance, for each parameter was selected using the lowest Akaike's information criterion. Statistical significance and tendencies were declared at $p \leq 0.05$ and $p \leq 0.10$, respectively. For FA analysis, a Proc GLM of SAS was used. Correlations between metabolic parameters and milk-related parameters were performed using PROC CORR of SAS. Syntaxes for SAS analysis are available in Appendix A.

\section{Results}

\subsection{Animal Performance}

Dry matter intake had a tendency $(p=0.09)$ to be affected by treatment $\times$ time with a numerical greater feed intake in TZD just prior to IMI and a numerically lower feed intake in TZD vs. CTR after IMI (Figure 2). Treatment did not affect milk yield, DMI, DE, or ECM (Figure 2). Similarly, TZD compared to CTR had not significant difference in body weight, body condition score (Figure S1), milk fat (Figure 2), or any of the other milk components (Table 1).

Table 1. Milk components in lactating goats injected daily with 2,4-thiazolidinedione (TZD) or saline (CTR).

\begin{tabular}{|c|c|c|c|c|c|c|c|c|c|c|c|c|c|c|}
\hline \multirow{2}{*}{ Parameter } & \multirow{2}{*}{ Group } & \multicolumn{9}{|c|}{ Day of Treatment } & \multirow{2}{*}{ SEM } & \multicolumn{3}{|c|}{$p$-Value ${ }^{1}$} \\
\hline & & 0 & 2 & 5 & 15 & 16 & 17 & 20 & 21 & 22 & & $\mathbf{Z}$ & Time & $\mathrm{Z} \times \mathrm{T}$ \\
\hline \multirow[t]{2}{*}{ Protein \% } & CTR & 2.32 & 2.29 & 2.22 & 2.32 & 2.35 & 2.28 & 2.41 & 2.41 & 2.39 & 0.09 & 0.30 & 0.10 & 0.78 \\
\hline & TZD & 2.32 & 2.26 & 2.19 & 2.18 & 2.18 & 2.17 & 2.21 & 2.21 & 2.19 & 0.09 & & & \\
\hline \multirow[t]{2}{*}{ Protein $\mathrm{g}^{2}$} & CTR & 18.3 & 19.4 & 18.2 & 20.3 & 18.2 & 17.0 & 19.2 & 18.4 & 18.1 & 2.5 & 0.98 & $<0.05$ & 0.76 \\
\hline & TZD & 18.3 & 20.4 & 17.9 & 18.9 & 18.2 & 17.5 & 18.4 & 19.2 & 19.0 & 2.5 & & & \\
\hline \multirow[t]{2}{*}{ Lactose $\%$} & CTR & 4.45 & 4.47 & 4.42 & 4.38 & 4.40 & 4.35 & 4.34 & 4.35 & 4.31 & 0.07 & 0.45 & $<0.05$ & 0.23 \\
\hline & TZD & 4.45 & 4.68 & 4.51 & 4.33 & 4.37 & 4.41 & 4.42 & 4.39 & 4.37 & 0.07 & & & \\
\hline \multirow{2}{*}{ Lactose $\mathrm{g}^{2}$} & CTR & 34.9 & 37.2 & 36.0 & 37.8 & 33.7 & 32.1 & 34.2 & 32.7 & 32.2 & 4.3 & 0.61 & $<0.05$ & 0.61 \\
\hline & TZD & 34.9 & 40.3 & 36.6 & 37.3 & 36.4 & 35.5 & 36.9 & 38.1 & 37.9 & 4.3 & & & \\
\hline \multirow[t]{2}{*}{$\mathrm{SNF}^{3} \%$} & CTR & 7.66 & 7.61 & 7.55 & 7.53 & 7.51 & 7.45 & 7.48 & 7.51 & 7.46 & 0.31 & 0.98 & 0.44 & 0.63 \\
\hline & TZD & 7.66 & 7.87 & 7.61 & 7.42 & 7.44 & 7.46 & 7.46 & 7.43 & 7.40 & 0.31 & & & \\
\hline \multirow[t]{2}{*}{$\mathrm{SNF}^{2}{ }^{2}$} & CTR & 60.2 & 64.6 & 61.5 & 65.4 & 57.8 & 55.1 & 59.2 & 56.8 & 56.0 & 7.6 & 0.69 & $<0.05$ & 0.67 \\
\hline & TZD & 60.2 & 69.3 & 62.0 & 64.1 & 62.1 & 60.2 & 62.1 & 64.5 & 64.2 & 7.6 & & & \\
\hline
\end{tabular}

${ }^{1} \mathrm{Z}=$ 2,4-thiazolidinedione effect; $\mathrm{T}=$ time; $\mathrm{Z} \times \mathrm{T}=2$,4-thiazolidinedione $\times$ time effect. ${ }^{2}$ Grams produced by the left mammary gland in the AM milking. ${ }^{3}$ Solid non-fat. 

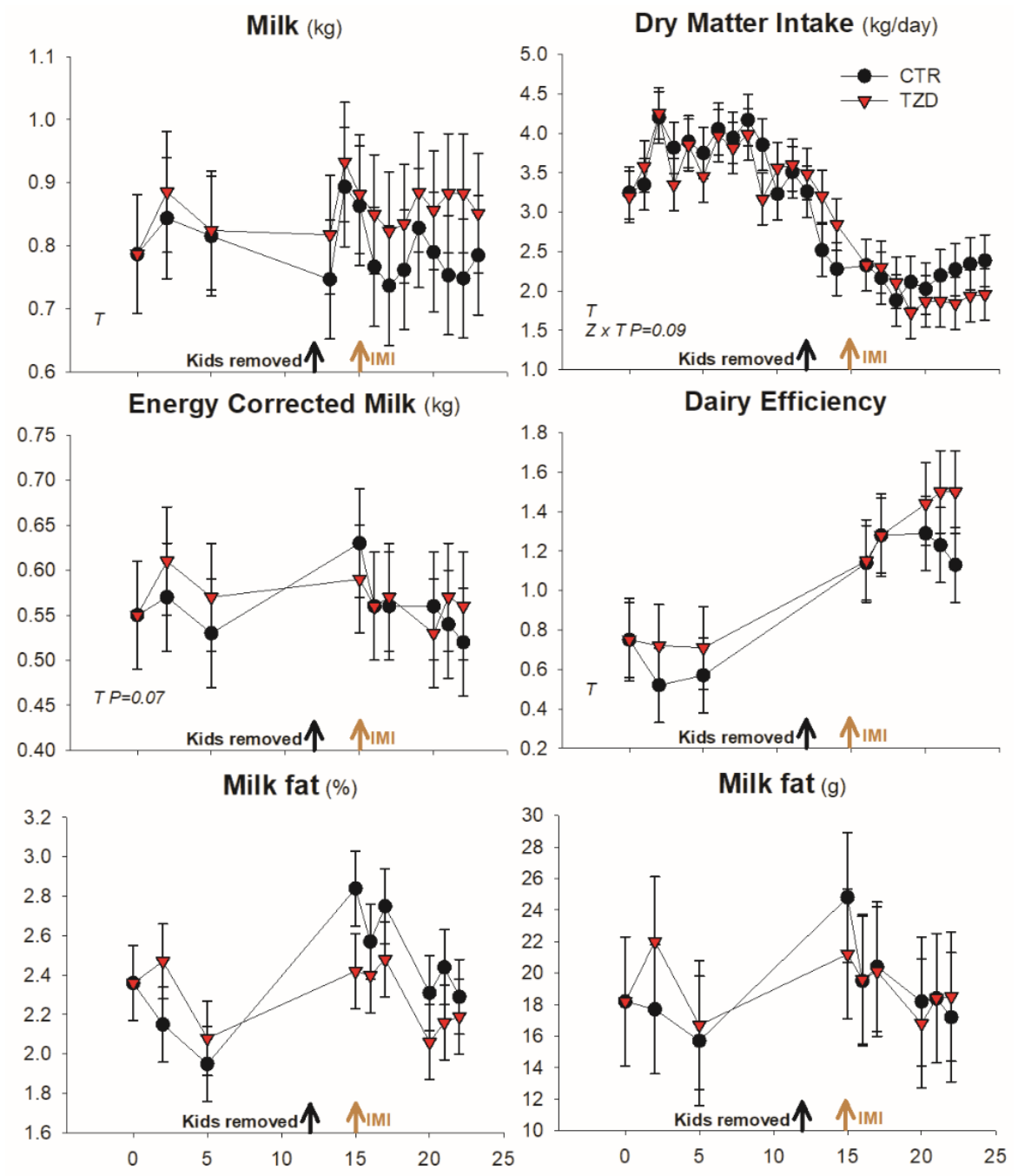

Milk fat $(\mathrm{g})$

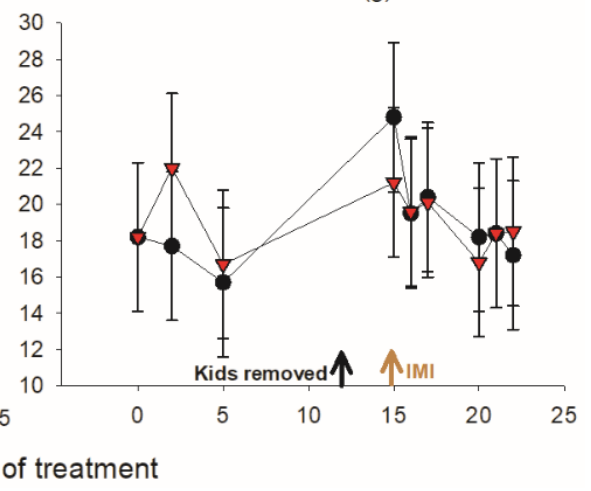

Figure 2. Milk yield (kg produced by the left mammary gland in the AM milking), energy corrected milk, dairy efficiency, daily dry matter intake, milk fat and milk yield (produced by the left mammary gland in the AM milking) in goats receiving daily intra-jugular injection of 2,4-thiazolidinedione (TZD) or saline (CTR). Arrows indicate the time of kid removal and intramammary infusion of Strep. uberis in the right half of the mammary gland (IMI). Letters in the graph denote significant $(p<0.05)$ effects of time $(\mathrm{T})$, treatment $(\mathrm{Z})$, and interactions $(\mathrm{Z} \times \mathrm{T})$. The reported $p$-value is for tendencies. Error bars denote SEM.

\subsection{Blood Metabolic Parameters}

2,4-TZD treatment significantly decreased NEFA, BHBA, and fatty acids available in plasma and increased glucose in blood (Figure 3; Table 2). Other parameters measured in plasma were not affected by 2,4-TZD treatment (Table 2). 


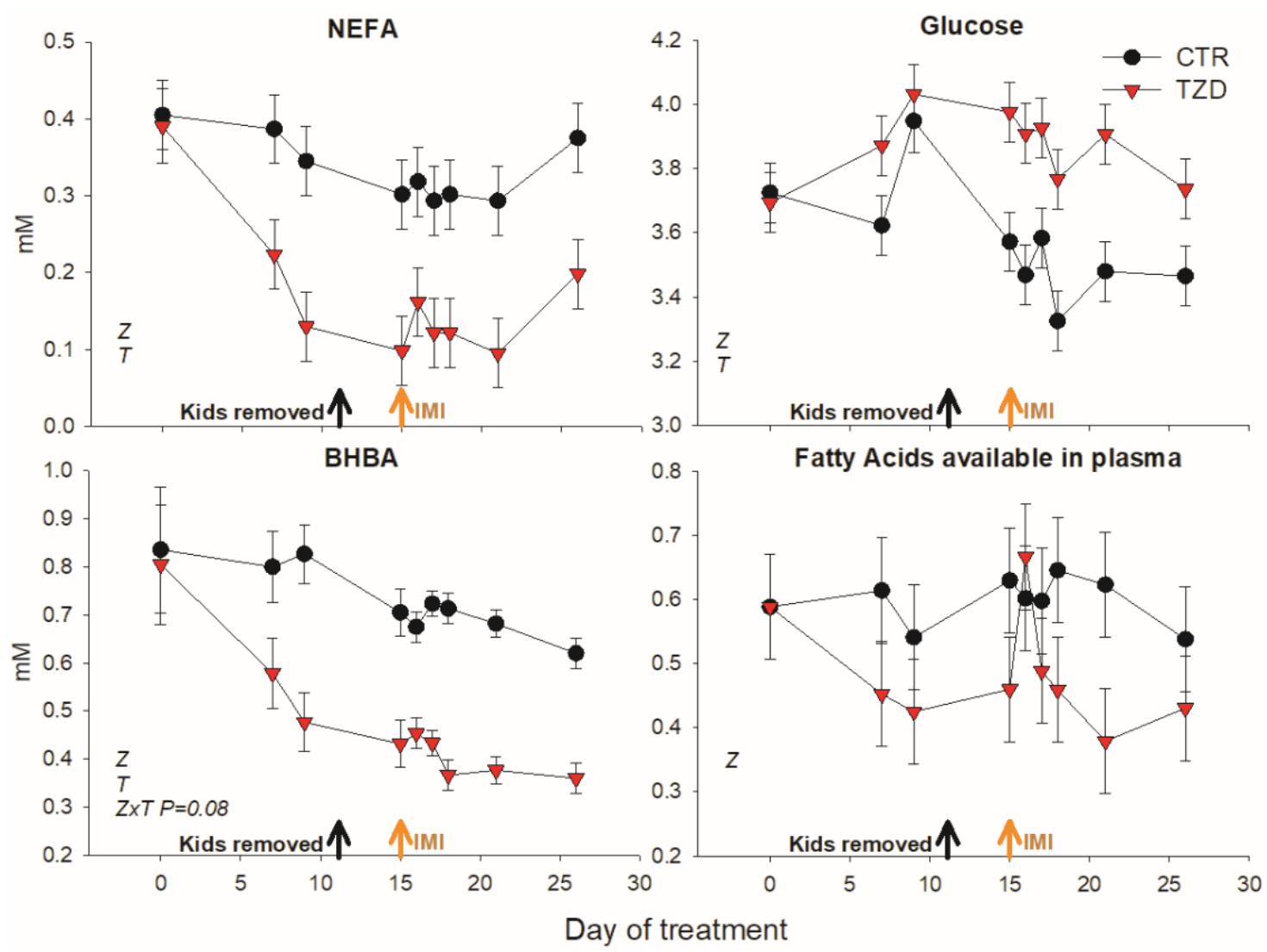

Figure 3. Non-esterified fatty acids (NEFA), glucose, $\beta$-hydroxybutyrate (BHBA), and estimated fatty acids present in plasma (mM NEFA $+3 \times \mathrm{mM}$ TAG) in goats receiving daily intra-jugular injection of 2,4-thiazolidinedione (TZD) or saline (CTR). Arrows indicate removal of kids and time of intramammary infusion of Strep. uberis in the right half of the mammary gland (IMI). Letters in the graph $(\mathrm{a}, \mathrm{b})$ denote significant effects of time $(\mathrm{T})$, treatment $(\mathrm{Z})$, and interactions $(\mathrm{Z} \times \mathrm{T})$. The reported $p$-value is for tendencies. Error bars denote SEM.

Table 2. Plasma concentration of metabolic parameters in dairy goats injected daily with 2,4-thiazolidinedione (TZD) or saline (CTR).

\begin{tabular}{|c|c|c|c|c|c|c|c|c|c|c|c|c|c|c|}
\hline \multirow{2}{*}{ Parameter } & \multirow{2}{*}{ Group } & \multicolumn{9}{|c|}{ Day of Treatment } & \multirow{2}{*}{ SEM } & \multicolumn{3}{|c|}{$p$-Value $^{1}$} \\
\hline & & 0 & 7 & 9 & 15 & 16 & 17 & 18 & 21 & 26 & & $\mathbf{Z}$ & Time & $\mathrm{Z} \times \mathrm{T}$ \\
\hline \multirow[t]{2}{*}{$\begin{array}{c}\text { Cholesterol, } \\
\mathrm{mM}\end{array}$} & CTR & 2.55 & 2.30 & 2.27 & 2.18 & 2.28 & 2.31 & 2.33 & 2.40 & 2.32 & 0.24 & 0.38 & 0.18 & 0.70 \\
\hline & TZD & 2.55 & 2.73 & 2.56 & 2.40 & 2.51 & 2.61 & 2.61 & 2.62 & 2.61 & 0.24 & & & \\
\hline \multirow[t]{2}{*}{$\Delta \mathrm{FA}, \%^{3}$} & CTR & 0.0 & 5.1 & -6.8 & 5.0 & 3.8 & 0.8 & 9.1 & 7.7 & -6.6 & 8.5 & 0.06 & 0.88 & 0.90 \\
\hline & TZD & 0.0 & -13.2 & -14.5 & -9.4 & -4.9 & -8.1 & -9.7 & -17.2 & -12.0 & 8.5 & & & \\
\hline \multirow[t]{2}{*}{ TAG, mM } & CTR & 0.14 & 0.15 & 0.16 & 0.19 & 0.17 & 0.18 & 0.19 & 0.19 & 0.13 & 0.02 & 0.89 & 0.30 & 0.82 \\
\hline & TZD & 0.14 & 0.14 & 0.15 & 0.19 & 0.19 & 0.19 & 0.18 & 0.16 & 0.15 & 0.02 & & & \\
\hline \multirow[t]{2}{*}{ Creatinine, $\mu \mathrm{M}$} & CTR & 71.9 & 77.3 & 77.1 & 71.9 & 72.6 & 70.2 & 70.4 & 72.2 & 75.8 & 2.7 & 0.98 & $<0.05$ & 0.94 \\
\hline & TZD & 71.9 & 76.6 & 77.6 & 70.7 & 72.2 & 71.7 & 70.6 & 72.4 & 76.1 & 2.7 & & & \\
\hline \multirow[t]{2}{*}{ Urea, mM } & CTR & 6.73 & 6.32 & 4.59 & 5.97 & 6.81 & 5.61 & 6.54 & 6.45 & 8.05 & 0.45 & 0.25 & $<0.05$ & 0.19 \\
\hline & TZD & 6.73 & 6.40 & 5.16 & 5.29 & 6.08 & 5.08 & 5.61 & 5.71 & 6.22 & 0.45 & & & \\
\hline
\end{tabular}

${ }^{1} \mathrm{Z}=2$,4-thiazolidinedione effect; $\mathrm{T}=$ time; $\mathrm{Z} \times \mathrm{T}=2,4$-thiazolidinedione $\times$ time effect. ${ }^{3}$ Percentage variation of total available fatty acids (as mM of NEFA $+(3 \times \mathrm{mM}$ of TAG)) compared to time 0 .

Results of correlation analysis between metabolic parameters, DMI, and milk-related parameters are available in Figure S2. Milk production was positively associated with DMI, glucose, and cholesterol level in blood, but was negatively associated with the level of urea in blood. Milk fat percentage was negatively associated with glucose and cholesterol in blood but was not associated with the level of NEFA or BHBA. 


\subsection{Adipocytes Size Distribution}

Adipocyte area was affected by treatment $\times$ time (Figure 4). 2,4-TZD treatment had a significant increase in the median area of adipocytes from Day 13 to Day 26 of treatment, while no changes were detected for the CTR goats. The effect was due to an increased frequency of large adipocytes in TZD vs. CTR goats, whereas the frequency of small-to-medium-sized adipocytes decreased (Figure 4).
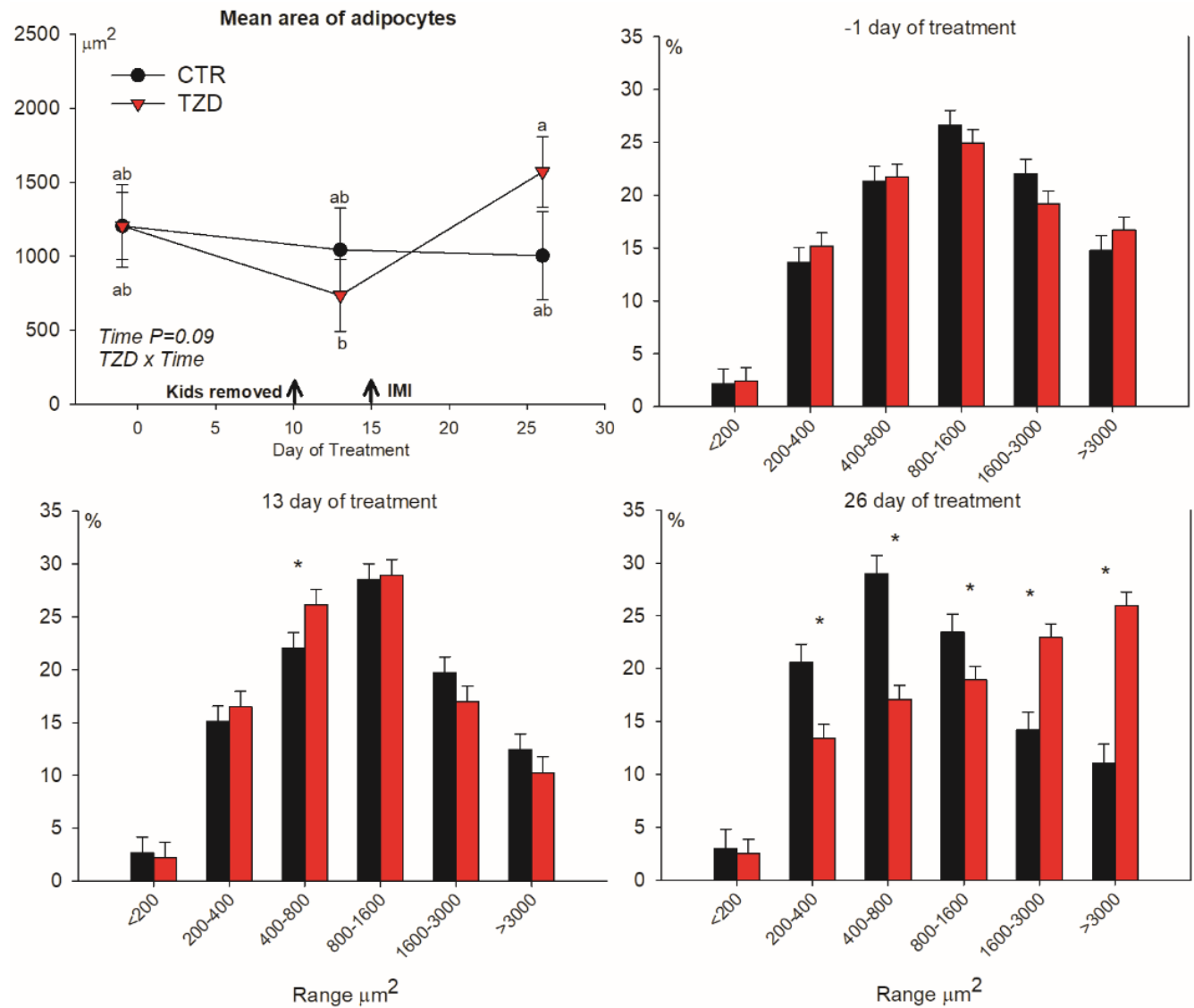

Figure 4. Median area of adipocytes and frequency (\%) in each specific range in area of adipocytes in subcutaneous tissue collected from the tail-head of goats receiving daily intra-jugular injection of 2,4-thiazolidinedione (TZD) or saline (CTR). Arrows indicate removal of kids and time of intramammary infusion of Strep. uberis in the right half of the mammary gland (IMI). Letters in the graph $(a, b)$ denote significant effects of time and interactions $(\mathrm{Z} \times \mathrm{T})$. Asterisks $\left({ }^{*}\right)$ denote differences $(p \leq 0.05)$ between treatments in the same range of area of adipocytes. Error bars denote SEM.

\subsection{Gene Expression}

\subsubsection{Subcutaneous Adipose Tissue}

Relative to CTR, 2,4-TZD treatment decreased the expression of CD36, coding for a major protein involved in LCFA import, but increased the expression of GAPDH and IRS1, tended to increase the transcript abundance of SLC2A4, and tended to decrease the expression of YWHAZ (Table 3). Among transcripts associated with glyceroneogenesis, we only detected a tendency (treatment $\times$ time $p=0.08$ ) for a higher expression of PDK4 in TZD vs. CTR at the end of the trial. 
Table 3. mRNA abundance of selected genes in adipose tissue of goats treated with 2,4-thiazolidinedione (TZD) or saline (CTR). Samples were $n \geq 5$ for both groups, except for the day 26 ( $n=3$ for CTR; $n=6$ for TZD).

\begin{tabular}{|c|c|c|c|c|c|c|c|c|}
\hline \multirow{2}{*}{ Gene } & \multirow{2}{*}{ Group } & \multicolumn{3}{|c|}{ Time } & \multirow{2}{*}{ SEM $^{1}$} & \multicolumn{3}{|c|}{$p$-Value $^{2}$} \\
\hline & & -1 & 13 & 26 & & $\mathbf{Z}$ & Time & $\mathrm{Z} \times \mathrm{T}$ \\
\hline \multicolumn{9}{|c|}{ Fatty Acids Import and De Novo Fatty Acid Synthesis } \\
\hline \multirow[t]{2}{*}{ CD36 } & CTR & 7169.8 & 6987.6 & 6233.3 & 681.3 & 0.03 & 0.03 & 0.03 \\
\hline & TZD & 7169.8 & 3362.5 & 5781.9 & & & & \\
\hline \multirow[t]{2}{*}{$L P L$} & CTR & 122.2 & 130.5 & 244.6 & 52.1 & 0.62 & 0.04 & 0.90 \\
\hline & TZD & 122.2 & 118.0 & 206.7 & & & & \\
\hline \multirow[t]{2}{*}{ SLC27A6 } & CTR & 0.09 & 0.12 & 0.11 & 0.03 & 0.84 & 0.15 & 0.94 \\
\hline & TZD & 0.09 & 0.14 & 0.11 & & & & \\
\hline \multirow[t]{2}{*}{$V L D L R$} & CTR & 2.3 & 2.0 & 1.0 & 0.9 & 0.67 & 0.48 & 0.25 \\
\hline & TZD & 2.3 & 1.1 & 2.7 & & & & \\
\hline \multirow[t]{2}{*}{$A C A C A$} & CTR & 37.6 & 26.6 & 48.5 & 24.3 & 0.33 & 0.51 & 0.14 \\
\hline & TZD & 37.6 & 88.6 & 45.6 & & & & \\
\hline \multirow[t]{2}{*}{ FASN } & CTR & 473.3 & 47.7 & 58.6 & 439.9 & 0.13 & 0.29 & 0.18 \\
\hline & TZD & 473.3 & 163.1 & 1328.2 & & & & \\
\hline \multirow[t]{2}{*}{ SCD1 } & CTR & 275.2 & 500.8 & 410.9 & 333.4 & 0.67 & 0.16 & 0.54 \\
\hline & TZD & 275.2 & 917.0 & 329.3 & & & & \\
\hline \multicolumn{9}{|c|}{ Insulin Signal and Glucose Metabolism } \\
\hline \multirow[t]{2}{*}{ GAPDH } & CTR & 159.2 & 125.6 & 91.2 & 41.7 & 0.01 & 0.25 & 0.08 \\
\hline & TZD & 159.2 & 271.2 & 195.9 & & & & \\
\hline \multirow[t]{2}{*}{ INSR } & CTR & 7.8 & 5.2 & 3.7 & 1.9 & 0.12 & 0.37 & 0.21 \\
\hline & TZD & 7.8 & 5.8 & 9.4 & & & & \\
\hline \multirow[t]{2}{*}{ IRS1 } & CTR & 9.2 & 6.8 & 4.6 & 2.0 & 0.04 & 0.42 & 0.05 \\
\hline & TZD & 9.2 & 7.4 & 12.5 & & & & \\
\hline \multirow[t]{2}{*}{ SLC2A4 } & CTR & 4.5 & 5.6 & 5.1 & 1.6 & 0.09 & 0.10 & 0.40 \\
\hline & TZD & 4.5 & 8.9 & 7.3 & & & & \\
\hline \multirow[t]{2}{*}{$Y W H A Z$} & CTR & 167.5 & 191.8 & 149.0 & 23.9 & 0.07 & 0.50 & 0.04 \\
\hline & TZD & 167.5 & 101.4 & 150.1 & & & & \\
\hline \multicolumn{9}{|c|}{ Glyceroneogenesis } \\
\hline \multirow[t]{2}{*}{ PCK1 } & CTR & 8.0 & 9.8 & 15.0 & 4.2 & 0.67 & 0.01 & 0.47 \\
\hline & TZD & 8.0 & 8.7 & 21.0 & & & & \\
\hline \multirow[t]{2}{*}{ PDK4 } & CTR & 1.8 & 1.2 & 1.1 & 0.4 & 0.66 & 0.03 & 0.08 \\
\hline & TZD & 1.8 & 0.8 & 2.1 & & & & \\
\hline \multirow[t]{2}{*}{ GPD1 } & CTR & 71.5 & 109.1 & 90.8 & 33.9 & 0.45 & 0.07 & 0.71 \\
\hline & TZD & 71.5 & 145.8 & 116.4 & & & & \\
\hline \multicolumn{9}{|c|}{ Transcription Regulation } \\
\hline \multirow[t]{2}{*}{ PPARG } & CTR & 43.5 & 41.7 & 49.5 & 9.6 & 0.81 & 0.19 & 0.70 \\
\hline & TZD & 43.5 & 37.3 & 58.3 & & & & \\
\hline SREBF1 & CTR & 16.1 & 19.3 & 23.0 & 16.7 & 0.61 & 0.38 & 0.61 \\
\hline & TZD & 16.1 & 14.8 & 44.7 & & & & \\
\hline
\end{tabular}

\subsubsection{Mammary Epithelial Cells}

Table 4 reports the results for the abundance of transcripts in mammary epithelial cells. The isolation of cells using cytokeratin 8 antibody significantly enriched cells expressing the specific epithelial marker KRT8; however, contrary to expectations, the expression of mammary-specific genes such as CSN3, LALBA, and FABP3 was higher in negative-cytokeratin 8 isolated cells compared with their positive counterparts. 
Table 4. Transcript abundance of selected genes normalized by the geometric mean of RPS9, UXT, and MRPL39 in mammary epithelial cells (MEC) in goats receiving 2,4-thiazolidinedione (TZD) or saline (CTR).

\begin{tabular}{|c|c|c|c|c|c|c|c|}
\hline \multirow{2}{*}{ Gene } & \multirow{2}{*}{ Group } & \multicolumn{2}{|c|}{ Cell $^{1}$} & \multirow{2}{*}{ SEM } & \multicolumn{3}{|c|}{$p$-Value ${ }^{2}$} \\
\hline & & Neg & Pos & & $\mathbf{Z}$ & Cell & $\mathrm{Z} \times$ Cell \\
\hline \multicolumn{8}{|c|}{ Mammary Epithelial-Specific Genes } \\
\hline \multirow[t]{2}{*}{ CSN3 } & CTR & 6324 & 3877 & 875 & 0.46 & $<0.05$ & 0.42 \\
\hline & TZD & 5050 & 3326 & 911 & & & \\
\hline \multirow[t]{2}{*}{ FABP3 } & CTR & 20.0 & 8.5 & 3.0 & 0.57 & $<0.05$ & 0.41 \\
\hline & TZD & 16.1 & 7.8 & 3.2 & & & \\
\hline \multirow[t]{2}{*}{$L A L B A$} & CTR & 1341 & 578 & 233.4 & 0.56 & $<0.05$ & 0.56 \\
\hline & TZD & 1065 & 501 & 251.7 & & & \\
\hline \multirow[t]{2}{*}{ KRT8 (Ln) ${ }^{3}$} & CTR & 1.78 & 2.50 & 0.27 & 0.30 & $<0.05$ & 0.64 \\
\hline & TZD & 1.48 & 2.03 & 0.29 & & & \\
\hline \multicolumn{8}{|c|}{ Fatty Acid Transport and Synthesis } \\
\hline \multirow[t]{2}{*}{$L P L$} & CTR & 9.68 & 4.87 & 1.52 & 0.70 & $<0.05$ & 0.77 \\
\hline & TZD & 10.8 & 5.19 & 1.68 & & & \\
\hline \multirow[t]{2}{*}{ CD36 } & CTR & 1300 & 979 & 104 & 0.30 & $<0.05$ & 0.87 \\
\hline & TZD & 1445 & 1094 & 115 & & & \\
\hline \multirow[t]{2}{*}{$V L D L R$ (Ln) } & CTR & 0.57 & 0.84 & 0.13 & 0.21 & $<0.05$ & 0.31 \\
\hline & TZD & 0.43 & 0.53 & 0.14 & & & \\
\hline \multirow[t]{2}{*}{$A C A C A$} & CTR & 0.29 & 0.58 & 0.09 & 0.99 & 0.09 & 0.10 \\
\hline & TZD & 0.43 & 0.43 & 0.10 & & & \\
\hline \multirow[t]{2}{*}{ SCD1 } & CTR & 5.84 & 5.03 & 0.68 & 0.06 & 0.02 & 0.53 \\
\hline & TZD & 4.19 & 2.89 & 0.71 & & & \\
\hline \multicolumn{8}{|c|}{ Transcriptional Regulation } \\
\hline \multirow[t]{2}{*}{ NFE2L2 } & CTR & 51.2 & 62.0 & 12.3 & 0.30 & $<0.05$ & 0.50 \\
\hline & TZD & 66.4 & 83.7 & 12.6 & & & \\
\hline \multirow[t]{2}{*}{ NRF1 } & CTR & 0.15 & 0.17 & 0.03 & 0.69 & 0.50 & 0.91 \\
\hline & TZD & 0.17 & 0.18 & 0.03 & & & \\
\hline \multirow[t]{2}{*}{ PPARG (Ln) } & CTR & -2.73 & -1.94 & 0.33 & 0.38 & $<0.05$ & 0.50 \\
\hline & TZD & -2.20 & -1.71 & 0.35 & & & \\
\hline \multirow[t]{2}{*}{ SREBF1 } & CTR & 0.85 & 1.17 & 0.13 & 0.45 & $<0.05$ & 0.79 \\
\hline & TZD & 0.74 & 1.01 & 0.14 & & & \\
\hline \multicolumn{8}{|l|}{ Other } \\
\hline \multirow[t]{2}{*}{ GAPDH (Ln) } & CTR & 3.63 & 4.07 & 0.31 & 0.39 & $<0.05$ & 0.47 \\
\hline & TZD & 3.85 & 4.56 & 0.33 & & & \\
\hline \multirow[t]{2}{*}{ IL8 (Ln) } & CTR & 4.8 & 4.9 & 0.6 & 0.31 & 0.17 & 0.40 \\
\hline & TZD & 5.5 & 5.9 & 0.6 & & & \\
\hline \multirow[t]{2}{*}{ YWHAZ } & CTR & 31.6 & 40.7 & 8.3 & 0.64 & 0.19 & 0.61 \\
\hline & TZD & 39.1 & 43.3 & 8.3 & & & \\
\hline
\end{tabular}

Almost all transcripts measured were significantly affected by the cell isolation, with PPARG, GAPDH, NFE2L2, VLDLR, and SREBF1 being more abundant in cytokeratin 8-positive vs. cytokeratin 8-negative cells, and $L P L, C D 36$, and $S C D 1$ were more abundant in cytokeratin 8-negative vs. cytokeratin 8-positive cells. None of the measured transcripts were significantly affected by 2,4-TZD treatment except $S C D 1$, where 2,4-TZD treatment tended $(p=0.06)$ to decrease its expression in both cells types, and $A C A C A$, where expression tended to be increased $(p=0.10)$ by $2,4-$ TZD treatment in cytokeratin 8-negative cells. 


\subsection{Fatty Acid Profile in Milk}

We detected 46 fatty acids in the goat milk (Figure S3). 2,4-TZD treatment significantly $(p<0.05)$ increased the percentage in milk of saturated fatty acids stearic acid (C18:0) and behenic acid (C22:0) and several unsaturated fatty acids, including cis-7 C14:1, cis9 C16:1, (unspecified) trans C16:1, trans-9, cis-12, cis-15 C18:3 (Table S5). Furthermore, all-trans linolenic acid was increased by 2,4-TZD treatment, but the same treatment decreased the proportion of cis-12 C18:1 and C19:1 (Table S5). A significant or a tendency for treatment $\times$ time interaction for the percentage of cis9 C14:1, trans-16 C18:1, and C20:4n6 was detected, whereas a larger proportion over time was detected in TZD vs. CTR (Table S5).

When considering the $\mathrm{g}$ of FA/milking, only a numerically lower oleic acid $(\mathrm{C} 18: 1 ; p=0.13)$ and linoleic acid (C18:2; $p=0.11)$ and numerically higher behenic acid (C22:0; $p=0.10)$ in TZD vs. CTR goats were detected (Table S6). Among all desaturation indexes calculated, the $\Delta 9$ 18:1 desaturation index was significant lower in TZD vs. CTR (Tables S5 and S6).

\section{Discussion}

\subsection{2,4-TZD Induces Greater Glucose Utilization in the Adipose Tissue but Did Not Activate PPAR $\gamma$}

The thiazolidinedione family of molecules, including rosiglitazone and pioglitazone, are potent activators of PPAR $\gamma$, which is a key player in insulin sensitivity, glucose metabolism, lipid homeostasis, and adipogenesis [19-21]. In dairy cows, the use of thiazolidinedione molecules during the peripartal period, including 2,4-TZD and pioglitazone, consistently decrease blood NEFA in early lactation [7,22], except when used in non-pregnant dry cows [11]. The decrease of NEFA by thiazolidinedione molecules is a consequence of a positive effect on insulin sensitivity [15]. We did not measure insulin sensitivity in the present experiment, but data indicate a high insulin sensitivity in TZD vs. CTR goats. The improved insulin sensitivity in TZD vs. CTR goats is supported by large decrease of NEFA and, in adipose tissue, an upregulation of $I R S 1$, a gene related to insulin signaling [23], a tendency for a higher expression of $S L C 2 A 4$, coding for the insulin-regulated glucose transporter, and a larger transcription of GAPDH, a gene positively induced by insulin in rodents [24]. Increased insulin sensitivity by 2,4-TZD treatment was also suggested by data from our prior experiment [9]. The likely increase of insulin sensitivity in goats treated with 2,4-TZD in the present experiment is also supported by an increased size of adipocytes, considering that insulin induces lipogenesis [20].

Different from our prior experiment [9], in the present experiment, blood glucose was increased by 2,4-TZD treatment, corroborating prior observations in dairy cows $[7,11,22]$. The reason for the increased glucose in blood by 2,4-TZD despite a possible larger insulin sensitivity is unclear; however, the larger concentration of glucose together with gene expression data (SLC2A4 and GAPDH) indicated a larger import and utilization of glucose by the adipose tissue in TZD vs. CTR goats.

Glucose in adipose tissue of ruminants can be used for fatty acid synthesis, including the provision of NADPH even though acetate is the main source [25]. Larger glucose in plasma after treatment with $4 \mathrm{mg}$ 2,4-TZD/kg BW was also detected in early postpartum dairy cows [6] or in non-pregnant dry dairy cows [11]. The use of pioglitazone prepartum, but not postpartum, also increased glucose levels in dairy cows [7]. These data contrast what is generally observed in humans since thiazolidinedione molecules are classical glucose-lowering drugs. It is possible that the lower plasma NEFA by thiazolidinedione positively affected liver gluconeogenesis [26], increasing glucose in plasma. In the experiment by Smith and collaborators [6], 2,4-TZD tended to lower lactose yield. Similar to Yousefi and collaborators [7], we did not observe any effect of 2,4-TZD on lactose yield in our experiment. The above data indicate that a decrease in utilization of glucose by the mammary gland is not the main cause of the observed increase in hematic glucose.

Association of GAPDH expression/activity with adipogenesis has been documented in rodents [27]. The reason for such association remains elusive; however, the reaction of this enzyme is reversible producing dihydroxyacetone phosphate that is then used to produce glyceraldehyde 3-phosphate via GPD1 through the glyceroneogenesis pathway [28]. Glyceroneogenesis in adipose tissue increases 
in rodent pre-adipocytes treated with rosiglitazone or pioglitazone via induction of expression of phosphoenolpyruvate carboxykinase [29]. However, 2,4-TZD failed to affect the expression of PCK1 in our experiment, similar to data in bovine [11].

Our original hypothesis was that 2,4-TZD would have activated PPAR $\gamma$ in well-fed animals. Data clearly indicated that 2,4-TZD failed to activate PPAR $\gamma$ in the adipose tissue. The classical PPAR $\gamma$ target gene $L P L$ or previously indicated target genes, such as SREBF1 or SCD1 [1], were not affected by 2,4-TZD treatment, confirming prior data in cows [30] and goats [9]. Thus, we cannot attribute the decrease in NEFA and the effect on glucose metabolism-related genes in the adipose tissue to PPAR $\gamma$ activation. Further support for inadequate activation of PPAR $\gamma$ by 2,4-TZD is provided by the lack of increase in the frequency of newly formed small adipocytes compared to CTR since PPAR $\gamma$ is a key player in adipogenesis [19].

The tendency for transcription of PDK4 to be increased by 2,4-TZD in the adipose tissue in our experiment is of interest. This enzyme plays a crucial role in glucose metabolism and overall energy homeostasis by inhibiting pyruvate dehydrogenase, providing pyruvate for the formation of oxaloacetate that can be used for glyceroneogenesis [31]. Furthermore, it is a well-established PPAR $\beta / \delta$ target gene in monogastric animals [31] and in dairy cows [32]. Among PPAR isotypes, activation of PPAR $\beta / \delta$ induces a reduction of NEFA in porcine [33]. It is possible that $2,4-T Z D$ activated PPAR $\beta / \delta$ in the adipose tissue in our experiment. However, 2,4-TZD did not affect the expression of PDK4 in liver (see companion paper [13]).

Overall, our data suggested that 2,4-TZD increased the use of glucose by the adipose tissue, likely for glyceroneogenesis and, maybe, de novo fatty acid synthesis. The latter is partly supported by an increase in the size of adipocytes together with a numerically larger expression of FASN and a concomitant decreased expression of $C D 36$, important for preformed fatty acid import [34]. However, the effect of 2,4-TZD on the adipose tissue appears to be PPAR $\gamma$-independent. Although not possible to support with the present data, other mechanisms for the effect of 2,4-TZD on adipose tissue, such as the effect on mitochondria, the activation of AMPK, and/or heat shock response, are possible as previously reviewed [35].

\subsection{2,4-TZD Does Not Affect Milk Fat Synthesis}

Our original hypothesis was that 2,4-TZD would have increased milk fat synthesis by activating PPAR $\gamma$. We did not observe any effect of 2,4-TZD on milk fat synthesis. The lack of effect on milk fat synthesis might be indicating a positive effect of 2,4-TZD on milk fat synthesis, considering the large decrease of LCFA available for the mammary gland. Based on our estimates the decrease in NEFA lowered the available LCFA for the mammary gland, including the ones from the triglycerides present in the VLDL, up to $17 \%$. Milk fat is synthesized with about $50 \%$ of fatty acids coming from the preformed LCFA present in blood [8]. A positive association between NEFA in plasma and milk fat has been reported in cows [8]. This appeared to be the case from prior studies in periparturient dairy cows where a decrease in milk fat was detected as a consequence of lowered NEFA by 2,4-TZD or pioglitazone treatment [6,7]. NEFA concentration is, however, high during early postpartum (reaching values $>1 \mathrm{mM}$ ) and the uptake of NEFA by the mammary gland from the blood is highly dependent from its concentration [36]. Despite the above data, it has been determined that more than $98 \%$ of stearate in milk fat come from the blood TAG-rich lipoproteins [8]. Thus, a change in NEFA might not have affected milk fat in our experiment due to the relatively low NEFA $(<0.5 \mathrm{mM})$ as a consequence of the goats being in mid-lactation stage. The lack of any association between NEFA and the percentage of milk fat in our experiment corroborate the above findings.

We observed only a minor effect of 2,4-TZD on fatty acid composition of the milk, including LCFA with potential positive effects on human health. Among saturated fatty acids affected by 2,4-TZD in our study, stearic acid (C18:0) and behenic acid (C22:0) are known to decrease LDL or total cholesterol in humans and mice $[37,38]$. Among unsaturated LCFA, proportionally more abundant in TZD vs. CTR goats, punicic acid (C18:3c9,t11,c13) can aid in combating metabolic syndrome [39], and n-7 
trans-palmitoleate, abundant in dairy products (possibly the major isomers in our trans-palmitoleate), has been associated with a preventive role in diabetes [40].

The above data indicated that the lowered NEFA did not affect yield of milk fat and only slightly changed milk fat composition. Thus, the data indicated no effect of 2,4-TZD on milk fat synthesis. Gene expression data in MEC support such a conclusion. Despite the fact that the use of the cytokeratin 8 antibody did not enrich milk-secreting MEC from somatic cells, in both cells types isolated, none of the PPAR $\gamma$ target genes were affected by 2,4-TZD, corroborating our prior findings [9]. 2,4-TZD also did not affect the expression of NFE2L2 and NRF1, which code for transcription factors involved in mitochondrial biogenesis and anti-oxidant response [41] and have been previously shown to be upregulated by pioglitazone in bone marrow neuroblasts [42].

Unexpectedly, 2,4-TZD treatment decreased the expression of SCD1 in MEC. This gene codes for a protein that plays a key role in milk fat synthesis [34]. Inhibition of this protein is associated with a decrease in milk fat synthesis and its expression is consistently decreased during milk fat depression, as previously reviewed [8]. The decrease in expression of SCD1 in our experiment translated also in a decreased desaturation of stearate to oleic acid. Our data, however, indicated that SCD1 activity is not essential to maintain overall milk fat synthesis in goats, which is contrary to previous reports [8,34] but supports conclusions from a prior study in dairy cows [43].

\section{Conclusions}

Despite having animals in a good body condition and fed adequate levels of vitamin A, we failed to detect any increase in milk fat synthesis or expression of related genes in MEC by 2,4-TZD. The TZD treatment had, however, a large effect on the adipose tissue considering the decreased level of NEFA in blood and increased adipocyte size, while affecting the expression of genes related to insulin signaling and glucose metabolism. Our data clearly indicated that 2,4-TZD has a strong effect on adipose tissue but does not activate PPAR $\gamma$. This finding undermined the possibility of testing our original hypothesis.

Supplementary Materials: The following are available online at http:/www.mdpi.com/2306-7381/6/2/45/s1. File S1: CellProfiler pipeline for adipocytes size. File S2: KingFisher protocol file for MEC isolation. Table S1: Nutrient composition of the forages. Table S2: Rations fed. Table S3: Composition of vitamins drench. Table S4: Primer-pairs. Table S5: Fatty acid profile (\%) in milk. Table S6: Grams/milking of each fatty acid in milk. Figure S1: Body weight and body condition score. Figure S2: Pearson correlation ( $\mathrm{r}$ above and $p$-value below) among measured parameters in blood and milk (plus dry matter intake). Yellow to orange to red shade denotes the level of significance for the correlations that are either positive (green shade) or negative (blue shade). Figure S3: Percentage of the 46 detected fatty acids in goat milk in our experiment. The upper quadrant reports a representative GC chromatogram.

Author Contributions: Conceptualization: C.T.E. and M.B.; data curation: S.J., E.T. and M.B.; formal analysis: S.J., F.R., J.S.O., and M.B.; funding acquisition: C.T.E. and M.B.; investigation: F.R., M.M., J.S.O., J.L., and M.B.; methodology: S.J., F.R., J.S.O., E.T., S.F., G.C., and M.B.; project administration: M.B.; resources: E.T., S.F., G.C., and C.T.E.; supervision: C.T.E. and M.B.; validation: S.J., F.R., J.S.O., E.T., and M.B.; visualization: M.B.; writing—original draft: S.J., J.S.O., and M.B.; writing—review \& editing: F.R., M.M., J.L., E.T., S.F., G.C., C.T.E., and M.B.

Funding: This research was funded by the Oregon Beef Council.

Acknowledgments: The authors thank Seth Spencer (general manager of animal facilities at OSU) and Mary Smallman (manager of the OSU Sheep Center) for the support during the research project. The authors also acknowledge the help from Jennifer L. Belveal, Jaye Western, Alex van der Velde, and Jennifer J Bruton for the completion of the project.

Conflicts of Interest: The authors declare no conflict of interest.

\section{Appendix A. Supplementary Materials and Methods}

\section{Appendix A.1. Animal Management}

The goats were housed in individual pens at the Hogg Metabolism Barn at Oregon State University for the experiment. Goats were allowed ten days of adaptation to the new environment prior to starting the experiment. Each goat was nursed by 2 kids during the first 11 days of the experiment, except for 
one goat (in the TZD group), which had only one kid due to the unwillingness of the goat to nurse other kids.

Goats were fed twice a day at 7:00 a.m. and 7:00 p.m. with orchard grass hay and alfalfa hay. The ration was supplemented in the morning feeding with a commercial grain goat mix (Kountry Buffet, CHS Inc., Albany, OR, USA) and a mineral mix (SWEETLIX ${ }^{\circledR}$ Caprine Magnum-Milk Mineral, Fort Worth, TX, USA). Goats also received 1 cup of the commercial grain during milking.

Vitamins requirements (IU/d) ranged from 10,700 to 16,000 for vitamin A, from 2700 to 4000 for vitamin $\mathrm{D}$, and from 330 to 500 for vitamin $\mathrm{E}$. The drench was a mixture of a commercial water-soluble premix of vitamins and electrolytes (Durvet, MO, USA) plus vitamin D and E (generously provided by CHS Inc., Tangent, OR, USA). The vitamins were suspended in $50 \mathrm{~mL}$ of water and drenched by using a $60 \mathrm{~mL}$ syringe.

Appendix A.2. Dry Matter Intake, Energy Corrected Milk (ECM), Dairy Efficiency (DE), and Body Condition Score (BCS)

The DMI during the first 11 days of treatments also included the feed consumed by kids. The weights of the kids nursing the CTR and TZD goats were not different $(14.0 \pm 2.8 \mathrm{~kg}$ in CTR vs. $13.4 \pm 5.3 \mathrm{~kg}$ in TZD at 1 day prior to starting the treatment and $16.8 \pm 3.0 \mathrm{~kg}$ in CTR vs. $16.1 \pm 5.4 \mathrm{~kg}$ in TZD when weaned; in both cases the $p$-value was $>0.71$ ).

Kilograms of ECM were calculated [44] only for the morning milking of the left mammary gland as follows:

$$
\mathrm{kg} \text { milk } \times((38.3 \times \text { Fat } \mathrm{g} / \mathrm{kg}+24.2 \times \text { protein } \mathrm{g} / \mathrm{kg}+16.54 \times \text { lactose } \mathrm{g} / \mathrm{kg}+20.7) / 3140)
$$

The DE was calculated as kilograms of ECM produced in one milking by the left half of the mammary gland $/ \frac{1}{4}$ daily $\mathrm{kg}$ DMI.

The BCS was assessed using a 1-5 scale as previously described [45].

\section{Appendix A.3. Adipose Biopsy}

Subcutaneous adipose tissue was collected by biopsy as previously described [9] from alternate sides of the tail-head at around $1000 \mathrm{~h}$ and samples were flash frozen in liquid nitrogen.

\section{Appendix A.4. Histological Analysis of the Adipose Tissue}

Adipose tissue samples were sent to the Oregon Veterinary Diagnostic Laboratory for histological preparation. Adipose tissue was fixed in 10\% neutral buffered formalin, processed on Tissue-Tek VIP5 Tissue Processor (Sakura, Torrance, CA, USA), and embedded in Paraffin Type 9 (Richard-Allen Scientific, San Diego, CA, USA). Tissue sections were cut at $4-5$ microns on a Microm HM355S microtome and mounted on glass microscope slides. Slides were stained with a standard hematoxylin and eosin stain using the Thermo Shandon GLX Linear Slide Stainer (Thermo Scientific, Waltham, MA, USA). Slides were imaged with a 10× magnification objective using a Leica DM6000 microscope equipped with a DFC295 digital color camera (Leica Microsystems Inc., Buffalo Grove, IL, USA). The analysis of adipocytes size was performed using CellProfiler v.2.2.0 software [46]. Besides average area of adipocytes, the frequency of various ranges of area of adipocytes was measured to estimate the formation of new adipocytes (i.e., small size) and the formation of large adipocytes, i.e., the accumulation of triglycerides (CellProfiler pipeline is available in File S1).

\section{Appendix A.5. Mammary Epithelial Cells Isolation}

Milk samples were collected in $250 \mathrm{~mL}$ DNase/RNase free sterile tubes (430776, VWR, Radnor, PA, USA) and immediately placed on ice $\left(4^{\circ} \mathrm{C}\right)$ until isolation $(\sim 1 \mathrm{~h})$. Tubes were centrifuged at $1500 \times g$ for $10 \mathrm{~min}$ to pellet the cells. Cells were washed twice with $12 \mathrm{~mL}$ of sterile phosphate buffered saline (PBS, PBL06-500ML, VWR) and centrifuged at $1000 \times g$ for $5 \mathrm{~min}$. Before the last wash, the cells were passed 
through a cell strainer (BD Falcon-70 $\mu$ m nylon, 732-2758, VWR). The final pellet was resuspended in $1 \mathrm{~mL}$ of PBS solution plus 0.1\% BSA (AK8917-0100, Akron, OH, USA) and transferred to a $1.5 \mathrm{~mL}$ tube pre-wetted with the PBS $+0.1 \%$ BSA solution. Cell isolation was performed using the KingFisher Duo (5400100, Thermo Scientific) following the manufacturer's instructions for Thermo Scientific Dynabeads isolation with some modifications. In brief, a $1 \mathrm{~mL}$ solution of cells was transferred in a well of a sterile KingFisher Flex Microtiter Deepwell 96 plate (95040460, Thermo Scientific). In a new well, $2 \mu \mathrm{L}$ of the antibody against the epithelial-specific marker cytokeratin 8 (MA1-19037, Thermo Scientific, USA) was added in $1 \mathrm{~mL}$ PBS $+0.1 \%$ BSA solution. Twenty-five microliters of Dynabeads ${ }^{\circledR}$ Pan Mouse IgG (11041, Thermo Scientific) were added into an empty well of the plate diluted in $1 \mathrm{~mL}$ PBS $+0.1 \%$ BSA. The isolation steps consisted of washing the Dynabeads ${ }^{\circledR}$, followed by the conjugation of the antibody with the Dynabeads ${ }^{\circledR}$ by incubation for $30 \mathrm{~min}$ at $6{ }^{\circ} \mathrm{C}, 20 \mathrm{~min}$ incubation with the cells, and two washing steps. The KingFisher protocol file is available in File S2. We obtained $36.6 \times 10^{6} \pm 74.3 \times 10^{6}$ total cells from $250 \mathrm{~mL}$ of milk (146,550 MEC/mL of milk). Cells positively isolated by the magnetic beads and cells remaining after isolation were transferred to $1.5 \mathrm{~mL}$ tubes, pelleted by centrifugation at $1000 \times g$ at $4{ }^{\circ} \mathrm{C}$ for $5 \mathrm{~min}$ and re-suspended in $1 \mathrm{~mL}$ of cold TRIzol ${ }^{\circledR}$ (15596018, Thermo Scientific). The samples were stored at $-80{ }^{\circ} \mathrm{C}$ until RNA extraction.

\section{Appendix A.6. RT-qPCR}

Approximately $200 \mathrm{mg}$ of frozen adipose tissue samples were weighed and immediately placed into $1200 \mu \mathrm{L}$ of ice-cold TRIzol ${ }^{\circledR}$ in 2 mL RNase/DNase free tubes (Metal Bead beating tubes, 13117-50, Qiagen, USA), and 1 bead (69989, 5 mm, Qiagen, Germantown, MD, USA) per tube was added using the bead dispenser (69965, Qiagen). Tubes were loaded into a Bullet Blender Next Advance (Laboratory Instruments, USA) and samples were homogenized twice for $1 \mathrm{~min}$ at maximum speed with 1 min resting on ice. RNA was extracted following a previously published protocol [47] and RNA cleaning was performed using RNeasy Plus Mini Kit (74104, Qiagen) for MEC and RNeasy Plus Lipid Tissue Mini Kit (74804, Qiagen) for adipose samples following the manufacturer's instructions without DNA digestion. SpectraMax ${ }^{\circledR}$ Plus 384 (Molecular Devices, San Jose, CA, USA) was used to measure RNA concentration.

Amplicons not previously validated were cleaned with DNA Clean \& Concentrator Kit (11-302C, Zymo Research, Irvine, CA, USA) and sequenced at the CGRB. The sequencing product was confirmed through BLASTN (megablast) at the National Center for Biotechnology Information.

The cDNA synthesis and the RTqPCR were performed as previously described [9] by using $90 \mathrm{ng}$ of RNA for each $20 \mu \mathrm{L}$ reaction for MEC and $80 \mathrm{ng}$ for adipose tissue. The PCR analysis was performed using Power SYBR ${ }^{\circledR}$ Green PCR Master Mix (4368706, Thermo Scientific,) in a 7900HT PCR system (Applied Biosystems, Foster City, CA, USA), and final RT-qPCR data were obtained using LinRegPCR [48].

The genes ribosomal protein 9 (RPS9), ubiquitously-expressed transcript (UXT), tyrosine 3-monooxygenase/tryptophan 5-monooxygenase activation protein zeta polypeptide (YWHAZ), mitochondrial ribosomal protein L39 (MRPL39), and glyceraldehyde 3-phosphate dehydrogenase $(G A P D H)$ were tested as potential internal control genes (ICGs) using geNorm [49]. The reliability of the selected ICG and the stability of the normalization factor through the calculation of the pairwise variation $\mathrm{V}$ (the lower the better) were assessed. The most stable normalization was achieved using the geometric mean of RPS9, UXT, and MRPL39 in both tissues with a V-value of 0.122 for adipose samples and 0.146 for MEC.

The intra-assay variation for $\mathrm{qPCR}$ data was (\% coefficient of variation between technical replicates) $<10 \%$ (geometrial mean $5.5 \%$ ).

\section{Appendix A.7. Milking and Milk Sample Analysis}

Goats were milked using a portable milking machine with two claws. Teats of the goats were pre-dipped before milking and post-dipped after milking using $0.5 \%$ iodine solution. Milk samples 
were collected in $50 \mathrm{~mL}$ tubes with a preservative (Bronopol) and shipped for analysis using NIR at Willamette National Dairy Herd Information Association (Salem, OR, USA).

\section{Appendix A.8. Milk Fatty Acid Analysis}

FIM-FAME-6 mixture was used as an external standard ( $33 \mathrm{mg} / \mathrm{mL}, 2009$, Matreya, State College, PA, USA). The external standard was used to build a 5-point standard curve for each of the annotated compounds for the calculation of absolute amount of each detected fatty acid (quantity of the fatty acids not present in the external standard was determined using annotated fatty acids with same/similar carbon length and degree of saturation). Final fatty acid data were obtained as a percentage of total measured fatty acids and $g$ of each fatty acid in milk/day. The latter was obtained using the intercept and slope of the standard curve for each fatty acid using the external standard (linear regression $\geq$ 0.99) corrected by the internal standard (to obtain the $\mathrm{mg}$ fatty acid/mL of milk) and multiplied by milk produced by the left mammary gland $(\mathrm{kg} / \mathrm{d})$ for each goat. Lipids were extracted from milk, and fatty acid profiling was performed using gas chromatography as previously described [50].

\section{Appendix A.9. Blood Metabolites}

Blood samples were collected prior to the morning feeding from the jugular vein using 20-gauge BD Vacutainer needles and tubes, one containing serum clot activator and the other sodium heparin (BD Vacutainer ${ }^{\circledR}$, Becton Dickinson, Franklin Lakes, NJ, USA). After blood collection, tubes containing sodium heparin were placed on ice $\left(4{ }^{\circ} \mathrm{C}\right)$, while tubes with a clot activator were kept at room temperature ( $\sim 30 \mathrm{~min})$ until centrifugation. Serum and plasma were obtained by centrifugation at $1000 \times g$ for $15 \mathrm{~min}$. Aliquots of serum and plasma were frozen $\left(-80^{\circ} \mathrm{C}\right)$ until further analysis.

Aliquots of plasma and serum were shipped on dry ice to the Department of Animal Sciences, Food and Nutrition, Universitá Cattolica del Sacro Cuore, Piacenza, Italy, for metabolic profiling. The intra- and inter-assay variation for the parameters measured in plasma is available elsewhere [13,17].

Appendix A.10. Statistical Analysis

Prog Reg of SAS to determine outliers:

proc reg lineprinter;

model Parameter $=$ Time $/ \mathrm{r}$;

run;

Prog GLIMMIX of SAS with AR(1):

proc glimmix;

class TRT Time Goat;

model Parameter $=\mathrm{TRT} \mid \mathrm{Time} / \mathrm{ddfm}=\mathrm{kr}$;

random Time/Residual subject $=$ Goat type $=\operatorname{ar}(1)$;

lsmeans TRT|Time/diff lines;

Run;

Prog GLIMMIX of SAS with ARH(1):

proc glimmix;

class TRT Time Goat;

model Parameter $=\mathrm{TRT} \mid \mathrm{Time} / \mathrm{ddfm}=\mathrm{kr}$;

random Time/Residual subject $=$ Goat type $=\operatorname{arH}(1)$;

lsmeans TRT|Time/diff lines;

Run;

Prog GLIMMIX of SAS with Spatial Power:

proc glimmix; 


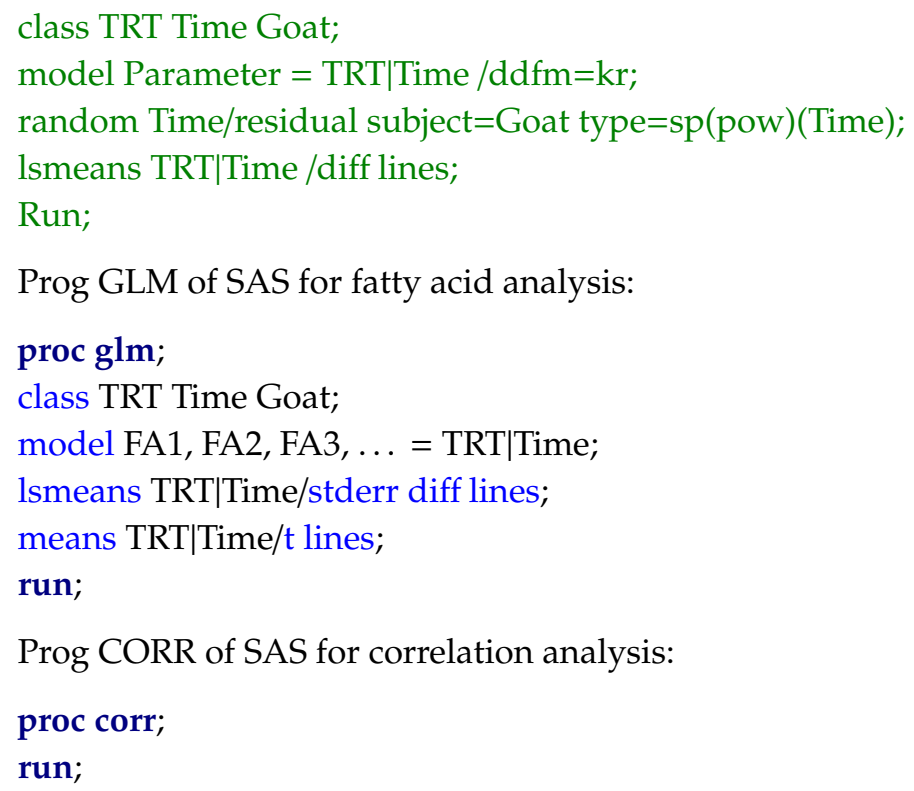

\section{References}

1. Bionaz, M.; Chen, S.; Khan, M.J.; Loor, J.J. Functional Role of PPARs in Ruminants: Potential Targets for Fine-Tuning Metabolism during Growth and Lactation. PPAR Res. 2013, 2013, 684159. [CrossRef]

2. Bionaz, M.; Osorio, J.; Loor, J.J. TRIENNIAL LACTATION SYMPOSIUM: Nutrigenomics in dairy cows: Nutrients, transcription factors, and techniques. J. Anim. Sci. 2015, 93, 5531-5553. [CrossRef] [PubMed]

3. Chen, Z.; Luo, J.; Ma, L.; Wang, H.; Cao, W.; Xu, H.; Zhu, J.; Sun, Y.; Li, J.; Yao, D.; et al. MiR130b-Regulation of PPARgamma Coactivator- 1alpha Suppresses Fat Metabolism in Goat Mammary Epithelial Cells. PLoS ONE 2015, 10, e0142809. [CrossRef]

4. Shi, H.B.; Zhao, W.S.; Zhang, C.H.; Shahzad, K.; Luo, J.; Loor, J.J. Transcriptome-Wide Analysis Reveals the Role of PPAR gamma Controlling the Lipid Metabolism in Goat Mammary Epithelial Cells. PPAR Res. 2016, 2016. [CrossRef]

5. Liu, L.; Lin, Y.; Liu, L.; Wang, L.; Bian, Y.; Gao, X.; Li, Q. Regulation of peroxisome proliferator-activated receptor gamma on milk fat synthesis in dairy cow mammary epithelial cells. In Vitro Cell. Dev. Biol. Anim. 2016, 52, 1044-1059. [CrossRef]

6. Smith, K.L.; Butler, W.R.; Overton, T.R. Effects of prepartum 2,4-thiazolidinedione on metabolism and performance in transition dairy cows. J. Dairy Sci. 2009, 92, 3623-3633. [CrossRef]

7. Yousefi, A.R.; Kohram, H.; Shahneh, A.Z.; Zamiri, M.J.; Fouladi-Nashta, A.A. Effects of dietary supplementation of pioglitazone on metabolism, milk yield, and reproductive performance in transition dairy cows. Theriogenology 2016, 85, 1540-1548. [CrossRef]

8. Palmquist, D.L. Milk Fat: Origin of Fatty Acids and Influence of Nutritional Factors Thereon. In Advanced Dairy Chemistry; Fox, P.F., McSweeney, P.L.H., Eds.; Springer: Boston, MA, USA, 2006; Volume 2.

9. Rosa, F.; Osorio, J.S.; Trevisi, E.; Yanqui-Rivera, F.; Estill, C.T.; Bionaz, M. 2,4-Thiazolidinedione Treatment Improves the Innate Immune Response in Dairy Goats with Induced Subclinical Mastitis. PPAR Res. 2017, 2017, 7097450. [CrossRef] [PubMed]

10. Schoenberg, K.M.; Perfield, K.L.; Farney, J.K.; Bradford, B.J.; Boisclair, Y.R.; Overton, T.R. Effects of prepartum 2,4-thiazolidinedione on insulin sensitivity, plasma concentrations of tumor necrosis factor-alpha and leptin, and adipose tissue gene expression. J. Dairy Sci. 2011, 94, 5523-5532. [CrossRef]

11. Hosseini, A.; Tariq, M.R.; da Rosa, F.T.; Kesser, J.; Iqbal, Z.; Mora, O.; Sauerwein, H.; Drackley, J.K.; Trevisi, E.; Loor, J.J. Insulin Sensitivity in Adipose and Skeletal Muscle Tissue of Dairy Cows in Response to Dietary Energy Level and 2,4-Thiazolidinedione (TZD). PLoS ONE 2015, 10, e0142633. [CrossRef]

12. Sandri, E.C.; Camera, M.; Sandri, E.M.; Harvatine, K.J.; De Oliveira, D.E. Peroxisome proliferator-activated receptor gamma (PPARgamma) agonist fails to overcome trans-10, cis-12 conjugated linoleic acid (CLA) inhibition of milk fat in dairy sheep. Anim. Int. J. Anim. Biosci. 2017. [CrossRef] 
13. Rosa, F.; Moridi, M.; Osorio, J.; Lohakare, J.; Trevisi, E.; Filley, S.; Estill, C.T.; Bionaz, M. 2,4-thiazolidinedione in well-fed lactating dairy goats: II. Response to intramammary infection. Vet. Sci. 2019, submitted.

14. National Research Council. Nutrient Requirements of Small Ruminants: Sheep, Goats, Cervids, and New World Camelids; National Academies Press: Washington, DC, USA, 2007.

15. Quinn, C.E.; Hamilton, P.K.; Lockhart, C.J.; McVeigh, G.E. Thiazolidinediones: Effects on insulin resistance and the cardiovascular system. Br. J. Pharmacol. 2008, 153, 636-645. [CrossRef] [PubMed]

16. Jain, V.S.; Vora, D.K.; Ramaa, C.S. Thiazolidine-2,4-diones: Progress towards multifarious applications. Bioorg. Med. Chem. 2013, 21, 1599-1620. [CrossRef]

17. Calamari, L.; Ferrari, A.; Minuti, A.; Trevisi, E. Assessment of the main plasma parameters included in a metabolic profile of dairy cow based on Fourier Transform mid-infrared spectroscopy: Preliminary results. BMC Vet. Res. 2016, 12, 4. [CrossRef] [PubMed]

18. Bionaz, M.; Trevisi, E.; Calamari, L.; Librandi, F.; Ferrari, A.; Bertoni, G. Plasma paraoxonase, health, inflammatory conditions, and liver function in transition dairy cows. J. Dairy Sci. 2007, 90, 1740-1750. [CrossRef] [PubMed]

19. Cui, T.T.; Xing, T.Y.; Chu, Y.K.; Li, H.; Wang, N. Genetic and epigenetic regulation of PPARgamma during adipogenesis. Yi Chuan Hereditas 2017, 39, 1066-1077. [CrossRef]

20. Boden, G.; Cheung, P.; Mozzoli, M.; Fried, S.K. Effect of thiazolidinediones on glucose and fatty acid metabolism in patients with type 2 diabetes. Metabolism 2003, 52, 753-759. [CrossRef]

21. Varga, T.; Czimmerer, Z.; Nagy, L. PPARs are a unique set of fatty acid regulated transcription factors controlling both lipid metabolism and inflammation. Biochim. Biophys. Acta 2011, 1812, 1007-1022. [CrossRef]

22. Smith, K.L.; Stebulis, S.E.; Waldron, M.R.; Overton, T.R. Prepartum 2,4-thiazolidinedione alters metabolic dynamics and dry matter intake of dairy cows. J. Dairy Sci. 2007, 90, 3660-3670. [CrossRef]

23. Guo, S. Insulin signaling, resistance, and the metabolic syndrome: Insights from mouse models into disease mechanisms. J. Endocrinol. 2014, 220, T1-T23. [CrossRef]

24. Alexander, M.C.; Lomanto, M.; Nasrin, N.; Ramaika, C. Insulin Stimulates Glyceraldehyde-3-Phosphate Dehydrogenase Gene-Expression through Cis-Acting DNA-Sequences. Proc. Natl. Acad. Sci. USA 1988, 85, 5092-5096. [CrossRef]

25. Nafikov, R.A.; Beitz, D.C. Carbohydrate and lipid metabolism in farm animals. J. Nutr. 2007, 137, $702-705$. [CrossRef] [PubMed]

26. Adewuyi, A.A.; Gruys, E.; van Eerdenburg, F.J. Non esterified fatty acids (NEFA) in dairy cattle. A review. Vet. Q. 2005, 27, 117-126. [CrossRef] [PubMed]

27. Dugail, I.; Quignard-Boulange, A.; Bazin, R.; Le Liepvre, X.; Lavau, M. Adipose-tissue-specific increase in glyceraldehyde-3-phosphate dehydrogenase activity and mRNA amounts in suckling pre-obese Zucker rats. Effect of weaning. Biochem. J. 1988, 254, 483-487. [CrossRef] [PubMed]

28. Hanson, R.W.; Reshef, L. Glyceroneogenesis revisited. Biochimie 2003, 85, 1199-1205. [CrossRef] [PubMed]

29. Tordjman, J.; Khazen, W.; Antoine, B.; Chauvet, G.; Quette, J.; Fouque, F.; Beale, E.G.; Benelli, C.; Forest, C. Regulation of glyceroneogenesis and phosphoenolpyruvate carboxykinase by fatty acids, retinoic acids and thiazolidinediones: Potential relevance to type 2 diabetes. Biochimie 2003, 85, 1213-1218. [CrossRef]

30. Schoenberg, K.M.; Overton, T.R. Effects of plane of nutrition and 2,4-thiazolidinedione on insulin responses and adipose tissue gene expression in dairy cattle during late gestation. J. Dairy Sci. 2011, 94, 6021-6035. [CrossRef] [PubMed]

31. Zhang, S.; Hulver, M.W.; McMillan, R.P.; Cline, M.A.; Gilbert, E.R. The pivotal role of pyruvate dehydrogenase kinases in metabolic flexibility. Nutr. Metab. 2014, 11, 10. [CrossRef]

32. Lohakare, J.; Osorio, J.S.; Bionaz, M. Peroxisome proliferator-activated receptor beta/delta does not regulate glucose uptake and lactose synthesis in bovine mammary epithelial cells cultivated in vitro. J. Dairy Res. 2018, 85, 295-302. [CrossRef]

33. Yu, Y.H.; Wang, P.H.; Cheng, W.T.K.; Mersmann, H.J.; Wu, S.C.; Ding, S.T. Porcine peroxisome proliferator-activated receptor delta mediates the lipolytic effects of dietary fish oil to reduce body fat deposition. J. Anim. Sci. 2010, 88, 2009-2018. [CrossRef] [PubMed]

34. Bionaz, M.; Loor, J.J. Gene networks driving bovine milk fat synthesis during the lactation cycle. BMC Genom. 2008, 9, 366. [CrossRef] [PubMed] 
35. Feinstein, D.L.; Spagnolo, A.; Akar, C.; Weinberg, G.; Murphy, P.; Gavrilyuk, V.; Russo, C.D. Receptor-independent actions of PPAR thiazolidinedione agonists: Is mitochondrial function the key? Biochem. Pharmacol. 2005, 70, 177-188. [CrossRef]

36. Miller, P.S.; Reis, B.L.; Calvert, C.C.; DePeters, E.J.; Baldwin, R.L. Patterns of nutrient uptake by the mammary glands of lactating dairy cows. J. Dairy Sci. 1991, 74, 3791-3799. [CrossRef]

37. Mensink, R.P. Effects of stearic acid on plasma lipid and lipoproteins in humans. Lipids 2005, 40, 1201-1205. [CrossRef]

38. Moreira, D.K.T.; Santos, P.S.; Gambero, A.; Macedo, G.A. Evaluation of structured lipids with behenic acid in the prevention of obesity. Food Res. Int. 2017, 95, 52-58. [CrossRef]

39. Shabbir, M.A.; Khan, M.R.; Saeed, M.; Pasha, I.; Khalil, A.A.; Siraj, N. Punicic acid: A striking health substance to combat metabolic syndromes in humans. Lipids Health Dis. 2017, 16, 99. [CrossRef] [PubMed]

40. Mozaffarian, D.; Otto, M.C.D.; Lemaitre, R.N.; Fretts, A.M.; Hotamisligil, G.; Tsai, M.Y.; Siscovick, D.S.; Nettleton, J.A. trans-Palmitoleic acid, other dairy fat biomarkers, and incident diabetes: The Multi-Ethnic Study of Atherosclerosis (MESA). Am. J. Clin. Nutr. 2013, 97, 854-861. [CrossRef]

41. Merry, T.L.; Ristow, M. Nuclear factor erythroid-derived 2-like 2 (NFE2L2, Nrf2) mediates exercise-induced mitochondrial biogenesis and the anti-oxidant response in mice. J. Physiol. 2016, 594, 5195-5207. [CrossRef] [PubMed]

42. Wang, Y.; Zhao, W.; Li, G.; Chen, J.; Guan, X.; Chen, X.; Guan, Z. Neuroprotective Effect and Mechanism of Thiazolidinedione on Dopaminergic Neurons In Vivo and In Vitro in Parkinson's Disease. PPAR Res. 2017, 2017, 4089214. [CrossRef]

43. Griinari, J.M.; Corl, B.A.; Lacy, S.H.; Chouinard, P.Y.; Nurmela, K.V.; Bauman, D.E. Conjugated linoleic acid is synthesized endogenously in lactating dairy cows by Delta(9)-desaturase. J. Nutr. 2000, 130, 2285-2291. [CrossRef] [PubMed]

44. Sjaunja, L.O.; Baevre, L.; Junkkarinene, L.; Pedersen, J.; Setala, J. A Nordic proposal for an energy corrected milk (ECM) formula. In Proceedings of the 27th Session of the International Commission for Breeding and Productivity of Milk Animals, Paris, France, 2-6 July 1990.

45. Villaquiran, M.; Gipson, T.A.; Merkel, R.C.; Goetsch, A.L.; Sahlu, T. Body Condition Scores in Goats. Am. Inst. Goat Res. 2004, 1-8.

46. Kamentsky, L.; Jones, T.R.; Fraser, A.; Bray, M.A.; Logan, D.J.; Madden, K.L.; Ljosa, V.; Rueden, C.; Eliceiri, K.W.; Carpenter, A.E. Improved structure, function and compatibility for CellProfiler: Modular high-throughput image analysis software. Bioinformatics 2011, 27, 1179-1180. [CrossRef]

47. Bionaz, M.; Loor, J.J. Identification of reference genes for quantitative real-time PCR in the bovine mammary gland during the lactation cycle. Physiol. Genom. 2007, 29, 312-319. [CrossRef]

48. Ramakers, C.; Ruijter, J.M.; Deprez, R.H.; Moorman, A.F. Assumption-free analysis of quantitative real-time polymerase chain reaction (PCR) data. Neurosci. Lett. 2003, 339, 62-66. [CrossRef]

49. Vandesompele, J.; De Preter, K.; Pattyn, F.; Poppe, B.; Van Roy, N.; de Paepe, A.; Speleman, F. Accurate normalization of real-time quantitative RT-PCR data by geometric averaging of multiple internal control genes. Genome Biol. 2002, 3. [CrossRef]

50. Oeffner, S.P.; Qu, Y.; Just, J.; Quezada, N.; Ramsing, E.; Keller, M.; Cherian, G.; Goddick, L.; Bobe, G. Effect of flaxseed supplementation rate and processing on the production, fatty acid profile, and texture of milk, butter, and cheese. J. Dairy Sci. 2013, 96, 1177-1188. [CrossRef]

(C) 2019 by the authors. Licensee MDPI, Basel, Switzerland. This article is an open access article distributed under the terms and conditions of the Creative Commons Attribution (CC BY) license (http://creativecommons.org/licenses/by/4.0/). 